\title{
ANTIOXIDANT ENZYME ACTIVITY AND FRESH-CUT ARRACACHA QUALITY
}

\author{
Atividade antioxidante de enzimas e qualidade da \\ mandioquinha-salsa minimamente processada
}

\author{
Hêmina Carla Vilela ${ }^{1}$, Patrícia de Fátima Pereira Goulart ${ }^{2}$, Kamila Rezende Dázio de Souza ${ }^{3}$, \\ Ana Carolina Vilas Boas ${ }^{3}$, Jane Silva Roda ${ }^{1}$, Roseane Maria Evangelista de Oliveira ${ }^{3}$
}

\begin{abstract}
The arracacha is an alternative of fresh-cut product; however it can be easily degraded after the processing techniques. The objective of this work was to evaluate the useful life of fresh-cut arracacha submitted to two types of cuts and storage, as well as to evaluate the activity of antioxidant enzymes. The roots were selected, sanitized and submitted to two cut types: cubed and grated. Then they were evaluated at 3 times: 0,3 and 7 days. The cutting in cubes provided higher quality and lower SOD, CAT and APX activity. However, the grated product presented higher PG activity and lower PPO activity. The microbiological safety and the nutritional value were maintained in both cuts during the whole storage period. The useful life, regarding the physicochemical, nutritional and microbiological aspects, can be established at 7 days under refrigeration for fresh-cut arracacha.
\end{abstract}

Index terms: Arracacia xanthorrhiza; minimally processed foods; oxidative stress; useful life; physicochemical aspects.

\section{RESUMO}

A mandioquinha-salsa apresenta-se como grande alternativa de produto minimamente processado, porém pode ser facilmente degradada após as técnicas de processamento. Objetivou-se, neste trabalho, avaliar a vida útil de mandioquinha-salsa, minimamente processada, submetidas a dois tipos de cortes e armazenamento, bem como avaliar a atividade de enzimas antioxidantes. As raízes foram selecionadas, sanitizadas e submetidas a dois tipos de corte: cubos e raladas. Em seguida, foram avaliadas em 3 tempos: 0, 3 e 7 dias. Por meio dos resultados obtidos, foi possível observar que o corte em cubos proporcionou ao produto maior qualidade e menor atividade de SOD, CAT e APX. O produto ralado apresentou maior atividade da PG e menor atividade da PPO. Ambos os cortes apresentaram segurança microbiológica, durante todo o período de armazenamento, além de manterem seu valor nutritivo. Conclui-se que a vida útil, sob os aspectos físico-químicos, nutricionais e microbiológicos, pode ser estabelecida em 7 dias sob refrigeração para mandioquinha-salsa submetida ao processamento mínimo.

Termos para indexação: Arracacia xanthorrhiza; alimentos minimamente processados; estresse oxidativo; vida de prateleira; aspectos físico químicos.

\section{INTRODUCTION}

Fresh-cut products are understood as fruits and vegetables whose natural form has been physically altered, however maintaining their fresh state. They undergo hygienic processing and are submitted to one or more physical alterations such as peeling, cutting and slicing, that make them fit for consumption (International Freshcut Produce Association-IFPA, 2002). The quality and the safety of those products are directly related to the manner of carrying out the processing, besides other factors such as: raw material quality, use of appropriate packaging and appropriate storage conditions (Cantwell; Suslow, 2002).

Faced with this, the search for fresh-cut products has been increasing in recent years. However those minimum processing in fruits and vegetables cause injuries and damage to the tissues. Although necessary, those processes increase the activity of some antioxidant enzymes (Catalase - CAT, Ascorbate peroxidase - APX, Superoxide dismutase - SOD and Polyphenoloxidase PPO) (Chitarra, 2002). According to Hard (2000), the action of those enzymes causes the appearance of strange odors, darkening of the vegetable or fruit and consequently reduces product quality and its useful life duration. Two of the enzymes that present a high relationship to enzymatic darkening are peroxidase and PPO and as such, the control of those enzymes is of extreme importance to obtain a processed product with quality (Clemente; Pastore, 1998).

The arracacha is a root which originates from the Andean region of South America (Venezuela, Colombia, Ecuador, Peru and Bolivia). It is a highly nutritious plant, however with higher commercial value than

${ }^{1}$ Centro Universitário de Lavras/UNILAVRAS - Lavras - MG - Brasil

${ }^{2}$ Centro Universitário de Lavras/UNILAVRAS - Rua Padre José Poggel - 506 - Bairro Centenário - $37200-000$ - Lavras - MG - Brasil pat.goulart@hotmail.com

${ }^{3}$ Universidade Federal de Lavras/UFLA - Lavras - MG - Brasil

Received in november 11, 2014 and approved in january 26, 2015

Ciênc. Agrotec., Lavras, v.39, n.3, p.276-282, maio/jun., 2015 
other vegetables (Madeira; Souza, 2005). It is a highly caloric food, since it possesses a high carbohydrate content, but with considerable amounts of vitamins and minerals (Sediyama et al., 2005). In this way, it is a food that is included in the diet of children, the elderly and convalescent individuals, demonstrating its high consumption (Santos, 1993).

In spite of the arracacha being a highly sought after fresh-cut vegetable (Machado, 2008), it is a highly perishable root, possibly occurring serious post harvest problems such as excessive fresh matter loss and microorganism contamination, not to mention that the perishability increases with physical processing. Injury to the cell tissue could occur, leading to an increase of the respiration rate, as well as the enzymatic darkening of the product, that alters its appearance and commercial value (Thompson, 1981).

Based on the above, care should be taken when conducting the minimum processing, mainly with the manner of conducting the cutting, sanitation, packaging and with regard to the product microbiological quality, since, with this root, one is dealing with a highly perishable food (Machado, 2008).

As such, the objective of the present work was to evaluate the useful life of fresh-cut arracacha, as well as to study the enzymatic behavior and the fresh-cut product quality, through physico-chemical and microbiologic analyses.

\section{MATERIAL AND METHODS}

In this experiment it was used arracacha from 'Amarela de Senador Amaral' cultivar. For the composition of the experimental groups, the plant material was acquired in the local commerce of Lavras, MG. The experiment was conducted in the Nutrition Laboratory of the Centro Universitário de Lavras and Plant Biochemistry and Molecular Physiology Laboratory and the Central Laboratory of the Food Science Department of the Federal University of Lavras.

The roots were selected as to absence of injuries, rottenness and odor characteristic of deterioration, washed with neutral detergent and sanitized with $25 \mathrm{mg} \mathrm{L}^{-1}$ sodium hypochlorite for 10 minutes for surface disinfection.

The minimum processing was made up of manual peeling in running water, with disinfected cutting utensils. The roots were then submitted to two types of cuts; straw-type grating and cubed, and were stored in rigid Polyethylene terephthalate (PET) packaging with individual covers forming Kits of $150 \mathrm{~g}$ each. Soon afterwards, they were stored under refrigeration at $4{ }^{\circ} \mathrm{C}$, for 7 days. All the analyses were carried out at three times: 0,3 and 7 days.

For the activity of the antioxidant enzymes such as SOD, CAT and APX the extraction was conducted by maceration of $0.2 \mathrm{~g}$ sample frozen in liquid nitrogen with the addition of $22 \mathrm{mg}$ PVPP, an antioxidant. Soon afterwards, the mash was transferred to an eppendorf containing $1.5 \mathrm{~mL}$ extraction buffer made up of: $375 \mu \mathrm{L}$ of potassium phosphate buffer $400 \mathrm{mM}, 15 \mu \mathrm{L}$ EDTA $10 \mathrm{mM}, 75 \mu \mathrm{L}$ ascorbic acid $200 \mathrm{mM}$ and $1035 \mu \mathrm{L}$ water. The extract was centrifuged at $12,000 \mathrm{rpm}$ for 30 minutes at $4{ }^{\circ} \mathrm{C}$ and the supernatant was collected and stored at $-20^{\circ} \mathrm{C}$ during the analyses period. The collected supernatants were used in the SOD, CAT and APX enzymatic analyses. The SOD activity was evaluated by the capacity of the enzyme to inhibit the photoreduction of the nitro blue tetrazolium (NBT), as proposed by Giannopolitis and Ries (1977). The CAT the activity was determined according to Havir and McHale (1987) and APX was verified according to the Nakano and Asada protocol (1981). The specific activity of the antioxidant enzymes was calculated based on the total amount of proteins of the samples determined according to Bradford (1976). The evaluation of the PPO activity was conducted according to the Folin-Denis method proposed by AOAC (2000).

For PG, its activity was verified according to Markovic, Heinrichová and Lenkey (1975). The enzymatic extract was obtained by the maceration of $1.5 \mathrm{~g}$ fresh matter (arracacha) frozen in liquid nitrogen and subsequent addition of $5 \mathrm{~mL} \mathrm{NaCl} 1 \mathrm{M}$. To the enzymatic extract, $1 \mathrm{~mL}$ of $0.25 \%$ citric pectin was added, and placed in water bath at $30^{\circ} \mathrm{C}$ for 3 hours. The reaction was stopped by sample boiling for 5 minutes. The sample deproteinization took place with $0.3 \mathrm{~N}$ barium hydroxide, $5 \%$ zinc sulfate and water. After filtration, aliquots of the deproteinate were used for determination of the enzymatic activity by the Somogy-Nelson method (Nelson, 1944). The activity was expressed in $\mu \mathrm{mol}$ of galacturonicacidmin ${ }^{-1} \mathrm{~g}^{-1}$ of fresh matter.

The $\mathrm{pH}$ analyses were conducted with a previously calibrated digital pHmeter by direct immersion in the sample, during the 7 days of product storage and always at the same time. The sample was prepared homogenizing $20 \mathrm{~g}$ dry matter in $80 \mathrm{~mL}$ water.

For the microbiological analyses were carried out based on the determination of the most probable number of coliforme group bacteria at $45^{\circ} \mathrm{C}(\mathrm{MPN} / \mathrm{g})$, according to the methodology recommended by the American Public Health Association (1992) and in 
agreement with the Brazilian legislation in force. The Secretaria Nacional de Vigilância Sanitária (National Department of Health Surveillance) establishes, for fresh vegetables, refrigerated or frozen, a coliforme MPN tolerance limit, at $45{ }^{\circ} \mathrm{C}$, up to $150 \mathrm{~g}^{-1}$ product. The calculation of coliforme MPN at $45{ }^{\circ} \mathrm{C}$ was made with the aid of the Hoskins table. The results were compared with the limits established according to RDC 12/2001, proposed by ANVISA.

The centesimal composition analyses were conducted according to the protocol proposed by AOAC (2000), with the purpose of expressing the nutritional value of the food.

The experimental design was completely randomized, with two treatments (cut types), three times $(0,3$ and 7$)$ and four replicates. The statistical analysis of the data was carried out using the SISVAR software (Ferreira, 2011), and the averages compared by the ScottKnott test to 5\% probability.

\section{RESULTS AND DISCUSSION}

Figure 1 displays the superoxide dismutase (SOD) enzyme activity of the fresh-cut product at different storage times and for the different cuts.

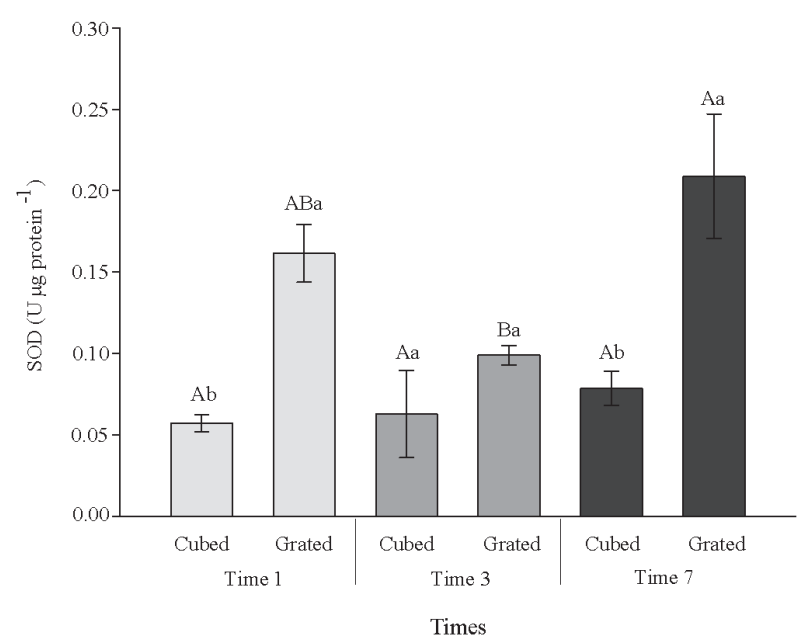

Figure 1: Superoxide dismutase (SOD) enzyme activity in fresh-cut arracacha submitted to different cuts. Capital letters compare the averages in the treatments over the three times, while the lower case letters compare among the treatments in each time based on Tukey's test $(p \leq 0.05)$. Error bars correspond to the standard error of the means.
The SOD activity, for the cubed treatment remained low and constant over all of the three times, while in the grated treatment was statically similar in T0 and in T7. At the three appraised times, the enzyme had higher activity in the grated cut than in the cubed cut. Due to the grated cut undergoing more friction than the cuts in cubes, higher damage occurs in the cellular tissue. Being such, it is a cut that tends to degrade more easily and consequently results in higher ROS production.

The CAT activity in arracacha is presented on Figure 2.

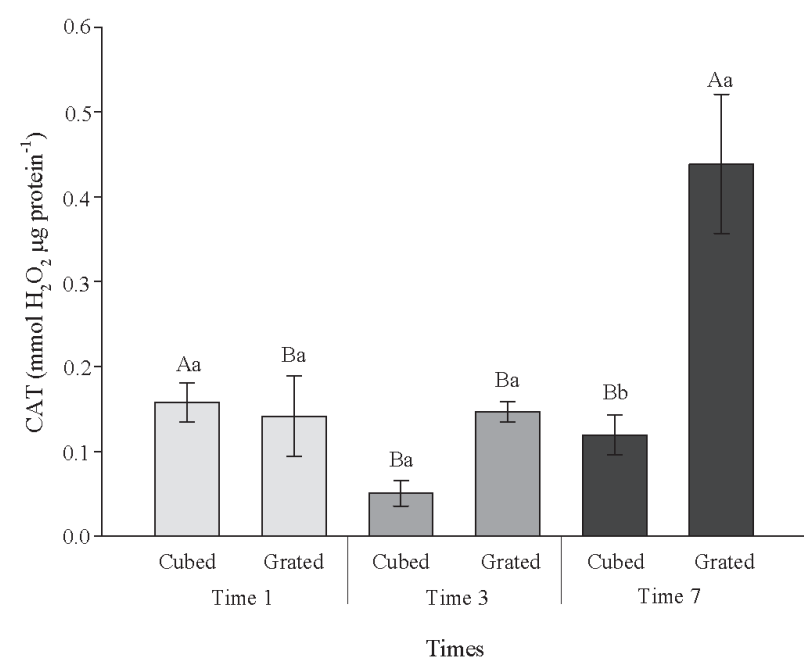

Figure 2: Catalase (CAT) activity in fresh-cut arracacha submitted to different cuts. Capital letters compare the averages in the treatments over the three times, while the lower case letters compare among the treatments in each time based on Tukey's test $(p \leq 0.05)$. Error bars correspond to the standard error of the means.

The CAT remained under low activity at $\mathrm{T} 0$, an expected result, since according to Sharma et al. (2012) CAT has low affinity by hydrogen peroxide, been more active at high ROS concentrations, proving its high activity at $\mathrm{T} 7 \mathrm{in}$ the grated cut.

Figure 3 displays the ascorbate peroxidase (APX) enzyme activity with the different times and cuts.

APX has high affinity by hydrogen peroxide (Gill; Tuteja, 2010), though this enzyme presents highest activity at low hydrogen peroxide concentrations (Inoue et al., 1994), thus indicating an expected activity, since at the beginning of the storage period ( $\mathrm{T} 0$ ), it had higher activity than at T7. The enzyme presented higher activity in the 
roots submitted to the cubed cut at $\mathrm{T} 0$, indicating that at that time, a lower ROS concentration exists, due to the tissue undergoing less damage during processing. Also, APX activity was lower in cubed cut than in the grated cut, showing that in the grated cut there was higher ROS generation, contributing to earlier loss of quality in these products.

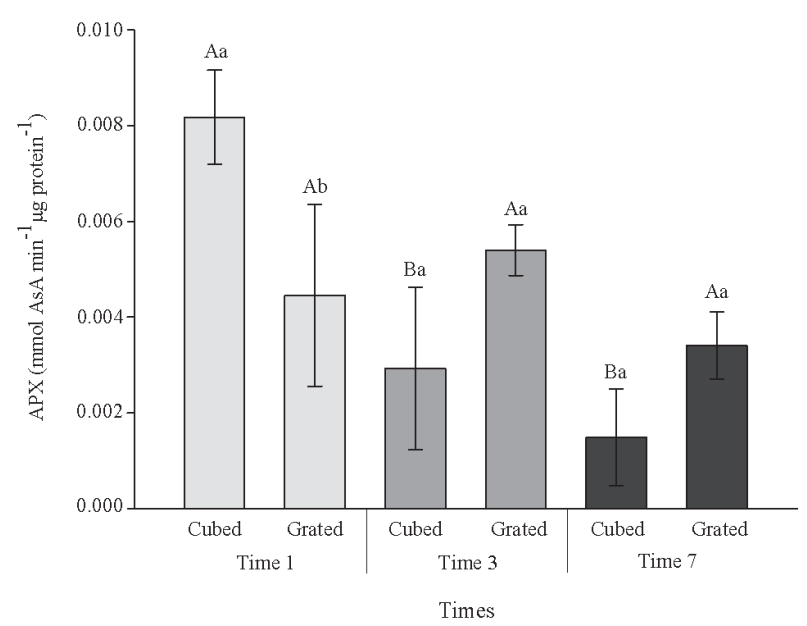

Figure 3: Ascorbate peroxidase (APX) enzyme activity in fresh-cut arracacha submitted to different cuts. Capital letters compare the averages in the treatments over the three times, while the lower case letters compare among the treatments in each time based on Tukey's test $(p \leq 0.05)$. Error bars correspond to the standard error of the means.

The superoxide dismutase, catalase and ascorbate peroxidase are antioxidant enzymes that act on the plant tissues as free radicals scavengers. Once the high concentrations of reactive oxygen species can lead to oxidative stress, the activity of the antioxidant system is very important to maintain cell homeostasis (Gill; Tuteja, 2010).

The polyphenoloxidases (PPO) act on phenolic compounds, causing their oxidation to quinones in the presence of $\mathrm{O}^{2}$, with darkening of the tissue due to its polymerization or to reaction with amino acids and proteins. Usually, the darkening occurs due to wounds in the product during harvesting, storage or processing operations (Chitarra; Chitarra, 2005). Figure 4 displays polyphenoloxidase (PPO) the enzyme activity during the experimental period.

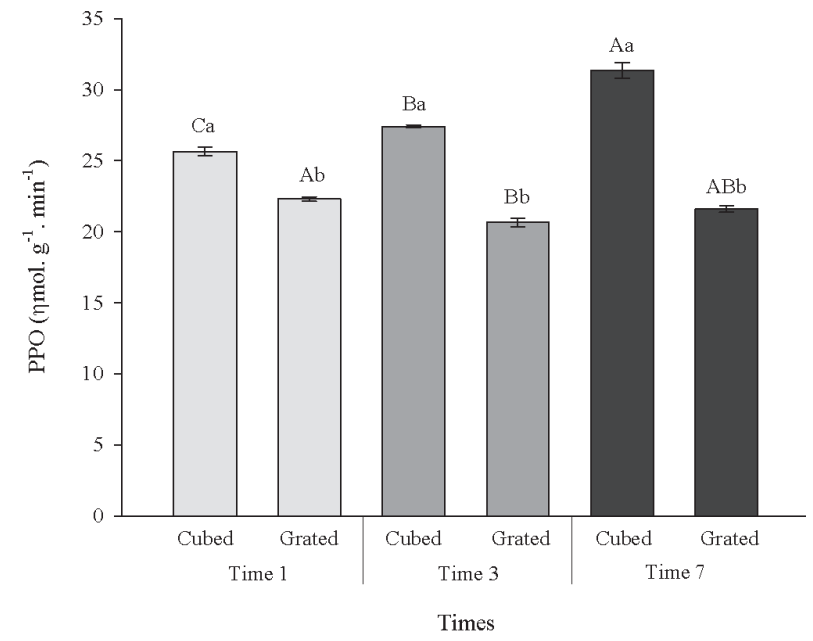

Figure 4: Polyphenoloxidase (PPO) enzyme activity in fresh-cut arracacha submitted to different cuts. Capital letters compare the averages in the treatments over the three times, while the lower case letters compare among the treatments in each time based on Tukey's test $(p \leq 0.05)$. Error bars correspond to the standard error of the means.

PPO is an enzyme that acts degrading catechol, its main substrate. The catechol in turn, is naturally present in arracacha, thus, it is normal that its activity is higher in the cubed cuts, because the roots are in larger sizes and consequently there is a higher catechol concentration in them than in the grated cuts. This was precisely the result observed during the storage period.

Various enzymes act on the cell wall of plant tissues, causing loss of product firmness during storage. Figure 5 displays the activity of the PG enzyme in the fresh-cut roots.

The pectic substances, derived from polygalacturonic acid, are mainly deposited in the cell wall, acting as binding material, being responsible for the textural changes of the fruits (Chitarra; Chitarra, 2005). PG catalyzes the hydrolysis of $\alpha-1,4$ bonds between two adjacent galacturonic acid residues(Seymour et al., 1987). The increase of the polygalacturonase activity during the period suggests that this enzyme should be the main responsible factor for pectin solubility during the softening process of the product. Furthermore, it is possible to observe that the grated product presented higher activity of this enzyme than the cubed cuts.

The $\mathrm{pH}$ values remained close to 6.91 for the cubed and 6.85 for the grated cuts, during every 
evaluation period, not presenting difference regarding the cut or storage time. Nunes et al. (2005) observed an average $\mathrm{pH}$ value of 6.79 in fresh-cut arracacha that did not undergo influence of the storage time. Alves et al. (2010) working with the same fresh-cut product observed $\mathrm{pH}$ values close to 6.84 . The $\mathrm{pH}$ results found in the present work approach the results found previously by other authors.

The Brazilian legislation has still not established microbiological standards for fresh-cut products. Therefore, the standards used are those that most approach such foods, in other words, for "Roots, tubers or the like, fresh, refrigerated, cut or frozen, for direct consumption", in agreement with the Resolution RDC $\mathrm{n}^{\circ} 12$ of January 02, 2001 of the National Agency of Sanitary Surveillance that stipulates $5 \times 10^{3} \mathrm{MPN} \mathrm{g}^{-1}$ for coliformes at $45^{\circ} \mathrm{C}$ (Brazil, 2001). As such, the roots of fresh-cut arracacha were within the established norms, since they presented values below the allowed limit.

In the centesimal composition analyses (Table 1), no alteration was verified among the appraised times, the cut types and the centesimal parameters, indicating that the nutritional value of the arracacha remained unaffected.

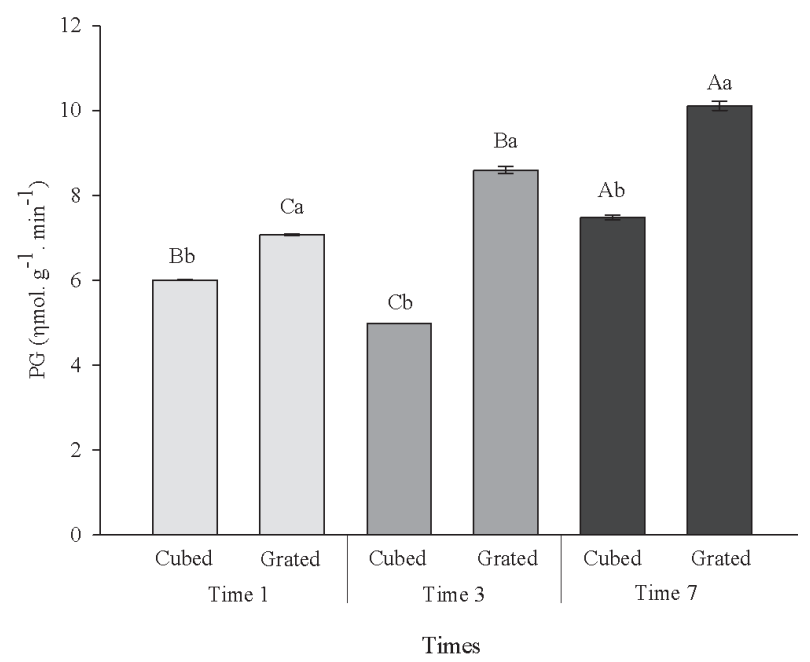

Figure 5: Polygalacturonase (PG) enzyme activity in fresh-cut arracacha submitted to different cuts. Capital letters compare the averages in the treatments over the three times, while the lower case letters compare among the treatments in each time based on Tukey's test $(p \leq 0.05)$. Error bars correspond to the standard error of the means.
Table 1: Analysis of centesimal composition.

\begin{tabular}{crrr}
\hline \multirow{2}{*}{ Parameters (\%) } & \multicolumn{3}{c}{ Time (days) } \\
\cline { 2 - 4 } & \multicolumn{1}{c}{0} & \multicolumn{1}{c}{3} & \multicolumn{1}{c}{7} \\
\hline MOISTURE & 73.70 & 73.32 & 73.88 \\
DRY MATTER & 26.30 & 26.68 & 26.12 \\
FAT & 1.70 & 1.80 & 1.75 \\
PROTEIN & 5.77 & 6.12 & 6.12 \\
FIXED MINERAL & 2.45 & 2.27 & 2.08 \\
RESIDUE (ASHES) & & & \\
FIBER & 9.80 & 9.40 & 9.60 \\
\hline
\end{tabular}

There were no differences in values between mode of sample preparation (Cubed and Grated).

\section{CONCLUSIONS}

Under the conditions of the present work, it can be concluded that cutting in cubes provided higher quality and lower SOD, CAT and APX activity to the fresh-cut product during storage. The grated product presented higher PG activity and lower PPO activity.

The $\mathrm{pH}$ values and the centesimal composition analyses did not vary regarding the time or cut type, the product thus maintaining its physiochemical and nutritional characteristics during the experimental period.

The microbiological analyses showed the safety of the product for up to 7 days of refrigerated storage.

\section{ACKNOWLEDGEMENTS}

The authors thank the Centro Universitário de Lavras (UNILAVRAS), CNPq and FAPEMIG, for their support.

\section{REFERENCES}

ALVES, J. A. et al. Qualidade de produto minimamente processado à base de abóbora, cenoura, chuchu e mandioquinha-salsa. Ciência e Tecnologia de Alimentos. 30 (3):625-634, 2010.

\section{AMERICAN PUBLIC HEALTH ASSOCIATION.}

Technical Commitee on Microbiological Methods for Foods. In: VANDERZANT, C., SPLITTSTOESSER, D. F. (Eds.). Compendium of methods for the microbiological examination of foods. 3 . ed. Washington: American Public Health Association, 1992. p.336-383. 
ASSOCIATION OF OFFICIAL AGRICULTURAL CHEMISTS - AOAC. Official methods of analysis of the association of official agricultural chemists. 12 . ed. Washington, 2000. 1094p.

BRADFORD, M. M. A rapid and sensitive method for the quantitation of microgram quantities of protein utilizing the principle of protein biding. Analytical Biochemistry. 72(1/2):248-254, 1976.

BRASIL. Ministério da Saúde. Agência Nacional de Vigilância Sanitária. Resolução RDC N. 12 de 2 jan. 2001. Aprova regulamento técnico sobre padrões microbiológicos para alimentos. Available in: <http://portal.anvisa.gov.br/wps/wcm/ connect/a47bab8047458b909541d53fbc4c6735/ RDC_12_2001.pdf?MOD=AJPERES $>$. Access in: jul. 02, 2012.10p.

CANTWELL, M. I.; SUSLOW, T. V. Postharvest handling systems: fresh cut fruits and vegetables. In: KADER, A. A. (Ed.). Postharvest technology of horticultural crops. 3. ed. Davis: California, 2002. p. $445-463$.

ClEMENTE, E.; PASTORE, G. M. Peroxidase and polyphenoloxidase, the importance for food technology. Ciência e Tecnologia de Alimentos. 32(2):167-171, 1998.

CHITARRA, M. I. F.; CHITARRA, A. B. Pós-colheita de frutos e hortaliças: fisiologia e manuseio. 2. ed. Lavras: UFLA, 2005. 785p.

CHITARRA, M. I. F. Processamento mínimo de frutos e hortaliças. Lavras: UFLA/FAEPE, 2002. 78p.

FERREIRA, D. F. Sisvar: a computer statistical analysis system. Ciência e Agrotecnologia. 35(6):1039-1042, 2011.

GIANNOPOLITIS, C. N.; RIES, S. K. Superoxide dismutases: I. Occurrence in higher plants. Plant Physiology. 59(2):309-314, 1977.

GILL, S. S.; TUTEJA, N. Reactive oxygen species and antioxidant machinery in abiotic stress tolerance in crop plants. Plant Physiology and Biochemistry. 48:909930, 2010.
HARD, N. F. Características de los tecidos vegetales. In: FENNEMA, O. R. (Dir.) Química de los alimentos. Zaragoza: Acríbia, 2000. p.1005-1009.

HAVIR, E. A.; MCHALE, N. A. Biochemical and developmental characterization of multiple forms of catalase in tobacco leaves. Plant Physiology. 84(2):450-455, 1987.

INTERNATIONAL FRESH-CUT PRODUCE ASSOCIATION - IFPA. 2002. Offering Global Expertise in Fresh-cut Produce: fresh-cut facts. Available in: < http://www.creativew.com/sites/ifpa/fcf. html>. Access in: jul. 02, 2012.

INOUE, M. Protective mechanism against reactive oxygen species In: ARIAS, I. M.; BOYER, J.; FAUSTO, N.; JACOBY, W.B.; SCHACHTER, D. A. (Eds.). The Liver Biology and Pathology. Ed. Raven Press, New York,1994. p.443-460.

MACHADO, M. C. M. Processamento. In: EMPRESA BRASILEIRA DE PESQUISA AGROPECUÁRIA. Mandioquinha-salsa (Arracacia xanthorrhiza). Brasília, 2008. Available in: $<$ http://www. sistemasdeproducao.cnptia.embrapa.br/FontesHTML/ Mandioquin...aSalsa/processamento.htm $>$. Access in: jul. 02, 2012. 15p.

MADEIRA, N. R., SOUZA, R. J. Mandioquinhasalsa: alternativa para o pequeno produtor. Lavras, (2005). Available in: < http:// www.editora.ufla.br/ boletim/pdf/bol_60.pdf. $>$ Access in: jul. 02, 2012.9p.

MARKOVIC, O.; HEINRICHOVÁ, K.; LENKEY, B. Pectolytic enzymes from banana. Collection Czechoslovak Chemistry Community. 40(3):769-774, 1975.

NELSON, N. A. A photometric adaptation of Somogyi method for the determination of glucose. Journal of Biological Chemistry. 153(1):375-380, 1944.

NAKANO, Y.; ASADA, K. Hydrogen peroxide is scavenged by ascorbate-specific peroxidase in spinach chloroplasts. Plant and Cell Physiology. 22(5):867880, 1981. 
NUNES, E. E. et al. Qualidade de mandioquinha-salsa minimamente processada e armazenada sob atmosfera modificada. Ciência Rural. 39(7):2185-2190, 2009.

SANTOS, F. F dos et al. A cultura da mandioquinhasalsa. Brasília: Empresa Brasileira de Pesquisa Agropecuária, Centro Nacional de Pesquisa de Hortaliças, EMBRAPA-SPI, 1993. 28p. (Coleção Plantar 3).

SEDIYAMA, M. A. N. et al.Cultura da Mandioquinha-salsa ou batata-baroa. Boletim Técnico da Empresa de Pesquisa Agropecuária de Minas Gerais, Belo Horizonte. 77:1-28, 2005.
SEYMOUR, G. B. et al. Polyuronide solubilisation during ripening of normal and mutant tomato fruit. Phytochemistry. 26(3):1871-1875, 1987.

SHARMA, P. et al. Reactive oxygen species, oxidative damage, and antioxidative defense mechanism in plants under stressful conditions. Journal of Botany, 2012. Available in: $<\mathrm{http}: / / \mathrm{www}$. hindawi.com/journals/jb/2012/217037/cta $>$. Access in: dec. 10, 2012.

THOMPSON, A.K. Reduction of losses during the marketing of arracacha (Arracacia xanthorrhiza). Acta Horticulturae. 116(1):55-60, 1981. 